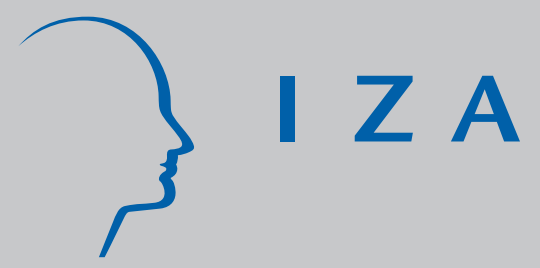

IZA DP No. 72

Are Austrian Returns to Education Falling Over Time?

J osef Fersterer

Rudolf Winter-Ebmer

November 1999 


\title{
Are Austrian Returns to Education Falling Over Time?
}

\author{
Josef Fersterer \\ University of Linz, Austria \\ Rudolf Winter-Ebmer \\ University of Linz, Austria, WIFO, IZA and CEPR
}

Discussion Paper No. 72

November 1999

\author{
IZA \\ P.O. Box 7240 \\ D-53072 Bonn \\ Germany \\ Tel.: +49-228-3894-0 \\ Fax: +49-228-3894-210 \\ Email: iza@iza.org
}

This Discussion Paper is issued within the framework of IZA's research area General Labor Economics. Any opinions expressed here are those of the author(s) and not those of the institute. Research disseminated by IZA may include views on policy, but the institute itself takes no institutional policy positions.

The Institute for the Study of Labor (IZA) in Bonn is a local and virtual international research center and a place of communication between science, politics and business. IZA is an independent, nonprofit limited liability company (Gesellschaft mit beschränkter Haftung) supported by the Deutsche Post AG. The center is associated with the University of Bonn and offers a stimulating research environment through its research networks, research support, and visitors and doctoral programs. IZA engages in (i) original and internationally competitive research in all fields of labor economics, (ii) development of policy concepts, and (iii) dissemination of research results and concepts to the interested public. The current research program deals with (1) mobility and flexibility of labor markets, (2) internationalization of labor markets and European integration, (3) the welfare state and labor markets, (4) labor markets in transition, (5) the future of work, (6) project evaluation and (7) general labor economics.

IZA Discussion Papers often represent preliminary work and are circulated to encourage discussion. Citation of such a paper should account for its provisional character. 
IZA Discussion Paper No. 72

November 1999

\section{ABSTRACT}

\section{Are Austrian Returns to Education Falling Over Time?*}

In this paper we make a systematic presentation of returns to education in Austria for the period 1981-1997. We use consistent cross-sections from the Mikrozensus and find falling returns over time. These falling returns are not caused by changes in the sample design and reduced willingness to reveal personal incomes in the survey. Moreover, it is shown that especially returns to university education have fallen. If the focus is not on mean returns, but if we apply quantile regression techniques, interesting patterns emerge: returns are falling the most in the lowest quantiles, but remain almost constant in the highest quantiles. The overall picture of falling returns is consistent with a rise in the supply of highly-educated workers in the recent two decades.

JEL Classification: I21, J31

Keywords: Returns to education, quantile regression, sample selection

Rudolf Winter-Ebmer

Institut für Volkswirtschaftslehre

University of Linz

Altenberger Str. 69

A - 4040 Linz

Austria

Tel: $++43-732-2468-236$

Fax: ++43-732-2468-238

Email: r.winterebmer@jk.uni-linz.ac.at

Financial support from the European Commission under the TSER programme PL980182 for the PURE project is gratefully acknowledged. Thanks to Helmut Hofer for generous help with the data organisation and Josef Zweimüller as well as participants at the $1^{\text {st }}$ Austrian Labour Economics Workshop for helpful comments. 


\section{Introduction}

Rising inequality in personal incomes is a well observed phenomenon in many countries. Rising inequality can take two specific forms: more inequality within skill groups and across skill groups. Inequality within skill groups can be caused by increasing fragmentation of jobs, new technologies and reduced wage compression efforts of unions and governments. Inequality across skill groups is different: here the first reasons are supply and demand of skills. Pinpointing changing skill differentials, i.e. by educational groups, has another important dimension: these differentials are important incentives for skill formation, school enrolment and training efforts.

In the U.S., skill differentials have increased a lot in the last two decades. Between 1961 and 1979 returns to a college education (compared to a high-school degree) have increased from $61 \%$ to $82 \%$ (Katz and Murphy, 1992). The situation is less clear in Europe. In the U.K. returns to education rose only modestly in the period 1978 to 1996 (Chevalier and Walker, 1999), whereas in Germany they remained fairly stable (Lauer and Steiner, 1999). In a comprehensive survey on empirical studies Psacharopoulos (1994) reports a drop in returns to a further year of schooling of around 2 percent over a period of 15 years. The only exception is university education, where returns have become higher over time. ${ }^{1}$

In this paper we look at returns to education in Austria for the period 1981-1997. This longer term view is possible by a systematic exploitation of the cross-sections of the Austrian Mikrozensus, which is a yearly $1 \%$ sample of the Austrian population. Unfortunately, data breaks hamper the analysis somewhat. Until 1987 graduates from teachers' academies were often coded incorrectly; up to 1993 net earnings were not recorded as such, but only net earnings together with children allowances. We correct for both of these data problems. Another problem is survey non-response with respect to the income question. As the respondents to the survey are not obliged to report their earnings, less and less do so over time. This high survey non-response rate of up to 50 percent has raised considerable doubts about the reliability of the Mikrozensus for issues of income distribution. We use sampleselection techniques to cope with this problem.

Previous research in Austria has only occasionally dealt with the development of returns to education. The study of returns to human capital was started by Christl (1984), but he used one cross-section only. Hofer and Pichelmann (1997) presented time-series from 1981-1993 for private sector workers only. Boss et al. (1997) were primarily interested in public-private sector wage profiles. Winter-Ebmer and Zweimüller (1994) investigated gender wage 
differentials, whereas Fersterer and Winter-Ebmer (1999b) look at specification issues of earnings functions. ${ }^{2}$ This paper is the first study to systematically investigate the changes in returns to education and their causes over time.

Section 2 discusses the data and the research framework. First results are discussed in section 3 where we find falling returns to education over time. We investigate if those falling returns are caused by the reduced willingness of interviewees over time to report their income. This turns out not to be the case. In section 4 reasons for this decline are assessed: the development of supply and demand for skills. Moreover, we look at returns for different qualification levels as well as to those at the upper and lower level of the income distribution by quantile regression to get a more comprehensive picture. Section 5 concludes.

\section{Data}

Ordinary least squares methods are applied to standard Mincerian earnings functions:

(1) $\quad \ln W_{i t}=\beta_{0}+\beta_{1 t} S_{i t}+\beta_{2 t} E X P_{i t}+\beta_{3 t} E X P_{i t}^{2}+u_{i t}$

The dependent variable $(\ln W)$ is net hourly wages in logarithmic terms, $S$ are years of schooling, EXP is potential experience and $u$, the error term, is assumed to be independent and identically normally distributed with fixed variance $\sigma^{2}$, which need not be constant over time. The index i refers to individuals $(\mathrm{i}=1, \ldots, \mathrm{n})$. All regressions were run for men and women separately and are performed for the period $\mathrm{t}=1981-1997$ every second year. This parsimonious specification has the advantage of easy comparability with other studies. It measures returns to education in a comprehensive way: all indirect influences of education on wages - e.g. the choice of better occupations and sectors - is attributed to education directly. We get, therefore, a reduced form coefficient for schooling. It should be clear, that all other variables usually used in wage regressions - industry, tenure, etc. - are potentially endogenous and influenced by education itself.

The question of endogeneity of schooling itself has again become an important research issue in the last decade. As educational attainment is a choice variable, there is ample reason to question simple OLS regression coefficients. Is the measured positive association between education and earnings a real causal relationship or would those who attain higher education

\footnotetext{
${ }^{1}$ See Ashenfelter et al (2000) for a recent meta-analysis of returns to schooling studies.

${ }^{2}$ See Fersterer and Winter-Ebmer (1999a) for a more detailed survey on research on returns to education in Austria.
} 
earn high wages anyway? Researchers have incorporated IQ tests as additional variables, they used twin studies or instrumental variable estimates to control for ability bias. Recent assessments of these studies conclude that, in fact, returns to education are somewhat higher using these methods: they increase on average by $1.8 \%$ for IV estimates and by $0.9 \%$ for twin studies as compared to OLS estimates (Card, 1999, Ashenfelter et al., 2000). ${ }^{3}$ Due to a lack of suitable instruments, which are also available over time, the question of endogeneity of schooling decisions cannot be properly dealt with here. ${ }^{4}$

We use the Austrian Mikrozensus, the only representative Austrian data set for such an analysis. These data are representative $1 \%$ household surveys, including detailed information about human capital variables. Net monthly earnings are reported in odd years only, so the cross-section regressions are run for every second year. Children allowances, which originally had been included in the earnings data until 1993, were eliminated throughout. Net hourly wages can then be constructed by dividing monthly earnings by (working hours per week $\mathrm{x}$ 4).

The Mikrozensus contains information about the highest completed level of schooling. We observe persons with apprentice training as well as graduates from vocational schools (berufsbildende mittlere Schulen - BMS), from secondary academic schools (allgemeinbildende höhere Schulen - AHS), from vocational colleges (berufsbildende höhere Schulen - BHS), and University. ${ }^{5}$ Years of schooling can easily be identified up to the secondary level ${ }^{6}$. Completing the tertiary level is assumed to last 17 years. For the framework with years of schooling one additional year of schooling has been added for people holding an apprenticeship degree (Lehrabschluß). Later on we use actual degrees attained to relax the assumption of linear returns to education by year. Graduates from teachers' academies were in the early years often incorrectly coded as secondary instead of tertiary educated persons. This mistake has been corrected in the Central Statistical Office by consistency checks since 1987. At first sight this led to a sharp increase of university graduates in the raw data, which turned out to be a statistical artefact. Therefore, before 1987, teachers had erroneously too little years of schooling, implying an upward bias of estimated rates of return. The bias is especially strong for females, because women attend teachers' colleges to a much higher extent than

\footnotetext{
${ }^{3}$ The inclusion of IQ tests to control for ability bias is controversial too, because it has to be guaranteed the test is not contaminated by schooling itself.

${ }^{4}$ Ichino and Winter-Ebmer (1998) present instrumental variables estimates for Austria for a very specific situation - the case of liquidity constrained students during the war -, which are considerably higher than corresponding OLS estimates. Due to this local average treatment effect (LATE), these results are not readily generalisable.

${ }^{5}$ This category comprises also the short non-university sector (Lehrerbildende Akademien)
} 
men. To our knowledge, this is the first study to properly address this issue. Several earlier studies excluded civil servants from the sample which avoids this consistency problem (see Fersterer and Winter-Ebmer (1999a) for more details).

There is no simple procedure to overcome this consistency problem. Especially, recoding the observations properly is impossible. In order to get comparable results over the entire period, we decided therefore to exclude teachers from our sample (about 200 males and 400 females in each year). This procedure also overcomes the problem, that information about hours worked of teachers should be considered with caution. There is no information about actual work experience or years of work interruption. Therefore we used potential experience defined as (age - years of schooling - 6) in the regressions. All employees (white-collar, bluecollar and civil servants) aged between 15 and 65 years are included in the sample. Apprentices have been eliminated from the analysed population.

Income taxes in Austria are highly progressive. It follows that net hourly wages of fulltime workers are lower compared to net hourly wages of part-time workers. Therefore, we opted for the following procedure: In a first step we eliminated all employees working less than 15 hours per week. Since only approximately $1 \%$ of the remaining male workers operate fewer than 35 hours per week we concentrated only on those workers who work full time. For women, we added a part-time dummy for those who work between 15 and 34 hours a week, since the fraction of female part-time workers is between 20 and 25 percent.

To avoid bias from incorrect income data (outliers) we omit all employees, whose net monthly wages are below the minimum contribution level (Mindestbeitragsgrenze) of the Social Security System. ${ }^{7}$

\section{Results}

Generally, we find a downward trend in the evolution of returns to schooling. Average returns to one additional year of education fell from $10.0 \%$ in 1981 to $7.4 \%$ in 1997 for men and from $11.4 \%$ to $8.0 \%$ for women. ${ }^{8}$ For international comparisons we can use the figures for the period 1995-1997: A mean return of 8\% per year of education is still high compared to an average of $6.4 \%$ for OECD countries Ashenfelter et al. (2000) find in their meta-analysis of OLS studies of returns to education.

\footnotetext{
${ }^{6}$ Only statutary years were coded; for individuals who had to repeat a year of secondary school, the actual number of years spent in school is underestimated.

${ }^{7}$ The minimum contribution level is routinely adapted to the inflation rate, it was ATS 2924 in 1991. Approximately 120 - 150 obervations (males and females) have been eliminated each year due to this condition.
} 
At the beginning of the period, average returns to schooling are slightly higher (about $1-2$ percentage points) for females than for males, but this difference disappears gradually. The estimates for males are somewhat higher compared to the figures presented by Hofer and Pichelmann $(1997)^{9}$, but the same trend over time is reproduced. As they control also for occupational status and industry, our higher results come from our "reduced form approach": we attribute all indirect effects also to education itself.

\subsection{Sample Selection Issues}

As already said in the introduction, there is a serious non-response problem in the data. Whereas the interviewees are obliged to answer all general demographic questions in the Mikrozensus "standard programme", answers to the income question are not obligatory. This procedure led to a significant number of missing income values (see Table 3). Over time the non-response rate increased from 20 to 50 percent. As there is a suspicion that non-response is more prevalent among high-income workers (Deutsch, 1996), we show also the non-response rates for university graduates. They are higher in earlier periods, but more similar to those of other respondents at the end of the period.

Apart from survey non-response, the fact that (rejected) wage offers by non-participants in the labour market are not observable, poses another problem. Besides loosing some observations, these sample selection problems could lead to serious biases if the selection is non-random, which is clearly what the basic labour supply models suggest. Both selection mechanisms follow different rules, therefore they should be modelled separately. As there is no significant proportion of non-participating males, we disregarded this problem. ${ }^{10}$ Instead we used a simple Heckman correction framework to deal with the non-response issue only.

For women the procedure is an extension of the Heckman's selection correction approach to a situation with two selection equations. Two indicator functions $\left(I_{1}, I_{2}\right)$ are estimated (indices $\mathrm{i}$ and $\mathrm{t}$ are omitted for clarity reasons). ${ }^{11}$

\footnotetext{
${ }^{8}$ If we disregard the coding problems for graduates from teachers' colleges, for women there is a huge artificial drop in returns between 1981 and 1987 of 4 percent.

${ }^{9}$ Hofer and Pichelmann (1997) use the same data set and estimate earnings functions from 1981 to 1993 for males, again every second year. Besides the standard human capital variables, they additionally include a dummy for white-collar workers and interaction terms between white-collar and experience and experience ${ }^{2}$, a vector of 8 industry dummies and a foreigner dummy in their regression. Moreover, they excluded civil servants from the analysed population.

${ }^{10}$ Given the very low rate of non-participation among males, the econometric framework of a bivariate selection equation would be highly unstable.

${ }^{11}$ See Tunali (1986) for the theory. Our presentation follows Zweimüller (1992) who first applied this framework to the problem of survey non-response and non-participation in a wage regression framework.
} 
(2) $I_{1}^{*}=x_{1} \alpha_{1}+\varepsilon_{1}$

(3) $I_{2}^{*}=x_{2} \alpha_{2}+\varepsilon_{2}$

$I_{1}$ measures the propensity to work, whereas $I_{2}$ measures the propensity to reveal the income. Both indicator variables have a latent structure with $I_{j}=1(j=1,2)$ if $I_{j}^{*} \geq 0, I_{j}=0$ else. The $x_{j}$ 's are explanatory variables and the $\alpha_{j}$ 's are coefficients to be estimated. Let the error terms $u, \varepsilon_{1}$ and $\varepsilon_{2}$ follow a trivariate normal distribution with mean zero and variances $\left(s_{e}^{2}, 1,1\right)$. Denote by $r$ the correlation between $\varepsilon_{1}$ and $\varepsilon_{2}$. This selection model is of a standard bivariate probit type with the exception that $I_{2}$ is unobservable in the case when the women does not work $\left(I_{l}=0\right)$. The likelihood function has to take this into account (bivariate probit with sample selection). It is given by

(4) $\quad L\left(\alpha_{1}, \alpha_{2} ; r\right)=\prod_{\mathrm{I}_{1}=0} F\left(-\alpha_{1}\right) \times \prod_{\left(I_{1}=1, I_{2}=0\right)} G\left(\alpha_{1}, \alpha_{2} ;-r\right) \times \prod_{\left(I_{1}=1, I_{2}=1\right)} G\left(\alpha_{1}, \alpha_{2} ; r\right)$

with $F$ as the cumulative density function of the univariate standard normal distribution and $G$ as the cumulative density function of the bivariate standard normal. From these bivariate probit coefficients Heckman correction terms can easily be calculated which are then included as additional regressors in the wage equation (1).

Results for the selection model as well as the wage equation for one year are presented in the Appendix. In the selection equations we need identifying variables, who convincingly do not influence wages. For work participation we use information of the partner/husband of the women and the number of children of different ages. In the case of the survey-response equation we use special features of the questionnaire: in general one person in the household was asked about demographics and wages of all household members. If the interviewee is asked about other family members' incomes, it is more likely that he cannot answer, i.e. there is no response to the income question. We use self-reporting as an identifying variable in the survey-response equation. Both sets of identifying assumptions can credibly be excluded from an ordinary wage equation. None-the-less they have a significant and numerically strong impact in the selection equations (see Appendix Table A1). ${ }^{12}$

\footnotetext{
${ }^{12}$ Zweimüller (1992) uses regional variables for the response equation, which in fact do explain response rates quite well and also finds that the effect of the selection on returns to education is minor. None-the-less the use of his identifying variables seems to be problematic because they do not fulfil the necessary exclusion restriction in the wage function.
} 
Although both selection correction terms are significant in the wage equation, the resulting changes for the returns to education are only minor. In Figure 1 results with and without sample selection correction are contrasted. All four graphs show a similar downward trend. For females, results with and without sample selection are practically the same, for males the corrected returns are half a percentage point higher in almost all years. Summing up, the reduced willingness to disclose one's income - especially in the higher income categories cannot explain the falling trend in returns to education.

\section{Some reasons for falling returns}

Why are then returns to education falling in Austria? We try to offer some insights into this topic by looking at the supply of graduates over time. Furthermore, it is important to leave the simple Mincerian framework of using years of schooling only by allowing different education (qualification) types to yield different returns. In doing so, we can see what is driving the decline in returns and if this decline is limited to specific groups. A final extension - quantile regression - allows us to look at the earnings advantage of additional years of schooling at different deciles of the earnings distribution. This approach gives also the opportunity to distinguish between wage dispersion between and within educational levels.

\subsection{Supply and Demand}

In a first step we investigate whether the observed pattern can be accounted for by a changing supply of more-educated workers. In Table 4 we report changes in the educational attainment of the adult population between 1981 and 1991. Whereas the proportion in the labour supply with only compulsory education decreased by $22 \%$ for males and $18 \%$ for females, all other population shares increased. This was particularly so for the most highly educated: those with secondary academic (AHS), vocational colleges (BHS) and those holding a university degree. The shares of these groups in the population increased between $25 \%$ for male vocational college graduates to $85 \%$ for female university graduates.

As a comparison we report in Table 5 the respective figures for the U.S. Because highschool enrolment in the U.S. started to take off already in the twenties (Goldin, 1998), we see much higher figures for 1981. The further increase in higher education in the U.S. was therefore more modest as compared to Austria. 
Following Katz and Murphy (1992) we divide our data into 60 distinct labour groups, distinguished by sex, 6 education categories (compulsory, apprenticeship, BMS, AHS, BHS and university) and 5 experience groups (0-8 years, 9-16, 17-24, 25-32 and 33-40). For these groups we calculate the change in relative supply $(\Delta s)$ over the period 1981 and 1997 as well as the change in mean wages $(\Delta \mathrm{w})$ relative to the grand mean. In Figure 6 , changes in relative wages are plotted against changes in relative supply. If the demand for skills remained constant over time, the development of wages should follow closely the changes in supply. This simple framework can give us a quick impression of the importance of demand changes, without being able to disentangle exactly the contributions of supply and demand. The picture in Figure 2 shows a significantly negative relation between changes in supply and changes in wages. The shown regression line is

$$
\begin{gathered}
\Delta w=-0.079-0.078 \Delta s \\
(0.012) \quad(0.015)
\end{gathered}
$$

$\mathrm{R}^{2}=0.286$ (Standard errors in par.)

This is certainly compatible with stable demand over time, i.e. the observed pattern of wage changes could in principle be explained by changes in supply alone. This pattern is in strong contrast to the situation in the U.S. Katz and Murphy (1992) obtain a flat relation between 1963 and 1971, a slightly negative relation between 1971 and 1979 and a highly positive relation between 1979 and 1987. For the whole period the relation between changes in relative supply and changes in relative wages is positive. In the case of the U.S. a stable factor demand structure has, therefore, to be rejected. The rising supply in more educated workers has been more than compensated by a rising demand for skills. For Austria - using this simple picture - we cannot rule out changes in the demand structure, but they were not strong enough to compensate the changes in relative supply.

\subsection{Returns to Educational Levels}

So far we used years of schooling as our measure of educational attainment. This crude measure will now be complemented with a more detailed investigation by looking at returns to specific school types. Assuming that the degree gained is more important than actual years spent on the school bench abandons the linearity assumption implicit in the years of schooling specification. $^{13}$

\footnotetext{
${ }^{13}$ This analysis cannot investigate the issue, whether degrees attained matter more than actual years spent in school - i.e. the so-called sheepskin effect (Hungerford and Solon, 1987). To do so we would need separate and
} 
Returns to different types of secondary and tertiary education for the whole period are presented in Figures 3 and 4 for males and females, respectively. The vertical axis reflects wage differentials (in percent) of graduates from a specific type of school compared to individuals with compulsory schooling only. As expected, returns to degrees achieved are rising unequivocally with required years of education. Note that the evolution of returns to educational levels are quite similar for both genders. Whereas returns to education for apprenticeship training (Lehre) and for vocational schools (BMS - 2-3 year courses) are remaining stable over time, returns to secondary academic (AHS) and secondary vocational colleges (BHS) are slightly falling within the period. The largest decrease in returns to education had to be accepted by university graduates: Whereas a university graduate could expect to earn almost $120 \%$ more compared to his/her colleague with only compulsory schooling in 1981 and 1983, this figure drops to less than 80\% in 1997. This fall in returns to university education corresponds closely to a survey by Lassnigg et al. (1998). Possible reasons are the development of supply but also the reduced employment opportunities in the public sector because of budget consolidation efforts in the last years. Whereas in 1975 and also in 1985 around $63 \%$ of graduates started a career in the public sector, this percentage dropped to $56 \%$ in 1995 (Lassnig et al., 1998, p. 29).

\subsection{Quantile Regressions}

Ordinary least squares (OLS) regression estimates the effects of exogenous variables on the mean of the conditional distribution of the dependent variable. However, this may be a too strong simplification, since exogenous variables may not only determine the mean but may also exercise an influence on other interesting parameters of the conditional distribution of the dependent variable (see Koenker and Basset, 1982, p.49). In contrast to OLS, quantile regression models allow to characterise the entire conditional distribution of the dependent variable.

As we have seen in the last sections, there is reason to believe that more educated workers find it more difficult over time to get adequate positions. A quantile regression framework is especially valuable in this respect, because it can investigate if returns to education are different at different quantiles of the distribution.

The quantile regression model can be written as (see Buchinsky, 1994)

independent data on years spent in schools and actual degrees attained, i.e. information on individuals who 
(6) $\ln w_{i}=x_{i} \beta_{\theta}+u_{\theta i} \quad$ with Quant $_{\theta}\left(\ln w_{i} \mid x_{i}\right)=x_{i} \beta_{\theta}$

where $x_{i}$ is the vector of exogenous variables and $\beta_{\theta}$ is the vector of parameters. Quant $_{\theta}(\ln w \mid x)$ denotes the $\theta$ th conditional quantile of $\ln w$ given $x$. The $\theta$ th regression quantile, $0<\theta<1$, is defined as a solution to the problem:

(7) $\min _{\beta \in R^{k}}\left\{\sum_{i: y_{i} \geq x_{i} \beta} \theta\left|\ln w_{i}-x_{i} \beta_{\theta}\right|+\sum_{i: y_{i}<x_{i} \beta}(1-\theta)\left|\ln w_{i}-x_{i} \beta_{\theta}\right|\right\}$

The median estimator of $\beta_{\theta}$ - with $\theta=0.5$ - is a special case of the quantile regression method. By variation of $\theta$, any quantile of the conditional distribution can be obtained. Since the minimisation problem has no explicit form, linear programming techniques are used to solve the problem in equation (7). In our study, standard errors of the estimates are obtained by bootstrapping with 100 repetitions. Estimates of quantile regressions are similarly interpreted like OLS regression estimates: they indicate the influence of exogenous variables $x$ on the $\theta$ th quantile of the endogenous variable $\ln w$.

Figures 5 and 6 graphically illustrate quantile regressions of Mincerian earnings functions for males in 1981 and 1993. The earnings functions relate (hourly) wages in logarithmic terms to years of schooling, (potential) experience and experience squared. In order to produce three dimensional graphs, we partialed out the effect of experience and its square on log hourly wages. The resulting residual - which is estimated by kernel density methods - therefore captures only the variation of the log wages due to schooling and due to other factors not included in the earnings function (e.g. ability, motivation). Assume for a moment, that the only unobserved variable is ability. An OLS regression would only identify returns to education for an individual with mean unobserved ability. In contrast to this, quantile regression can provide us with estimates for returns to education for an individual at, say, the $10^{\text {th }}$ percentile of the ability distribution, etc. Insofar, as the returns vary among individuals at different percentiles, quantile regression techniques provide additional information, unavailable by OLS. ${ }^{14}$ Moreover, we see that the variation in returns gets bigger over time.

repeated years or those who failed a program after enrolling for some years.

${ }^{14}$ The Figures also show nicely the relation of OLS regression and homoscedasticity of the error terms. OLS assumes that the errors are homoscedastic, whereas in our Figures 5 and 6 we see, that this is not the case, because the quantile regression lines diverge. 
This preliminary picture is corroborated once we explore the issue more systematically by running quantile regressions for $\theta=0.10,0.25,0.50,0.75$ and 0.90 over the whole period $\left(1981\right.$ - 1997) for men and women separately. ${ }^{15}$ Estimated returns to education over time at these quantiles are shown in Figures 7 and 8. Almost uniformly, estimated returns to education are higher at higher quantiles, i.e. at the upper end of the wage distribution. In all years results for the 25 and 75 percentile as well as those for the 10 and 90 percentile are significantly different from each other at the $1 \%$ level of significance. This means, that we do get more information by using quantile regressions. The returns behave very similarly for both genders over time. For both genders, the spread in returns to education between the 10 and 90 percentile widens over time - from 2 (2) percentage points in 1981 for women (men) to 4.8 (3.5) percentage points for women (men) in 1997. This widening of the spread is reached not symmetrically, but by a large drop in returns for the lower quantiles. On the other hand, returns at the upper end of the wage distribution remain mostly constant and drop only in the last two periods.

Four issues can be raised to interpret these results. First, the increasing spread in returns to education means that investing in schooling has become more risky over time. ${ }^{16}$ Taking riskavers individuals, higher risk by itself should lead to lower school enrolment. ${ }^{17}$ Second, falling returns to education at the lower end of the wage distribution can be seen as a pattern of "overeducation" (Sicherman, 1991, Dolton and Vignoles, 1997); high educated workers do not find adequate jobs according to their educational degree. Third, can we relate the spreading out of returns to education to inequality within educational levels? Equal returns to education for all quantiles would imply an identical distribution of conditional wages for all educational levels. Higher returns to education for the upper part of the earnings distribution means that within inequality (within educational levels) is higher among the more educated workers. The spreading out of returns, correspondingly, means that within inequality is increasing for more educated workers relative to within inequality among less educated workers. ${ }^{18}$ Fourth, higher returns at the higher end of the income distribution can be interpretated as an indication for complementarity between ability and education (Mwabu and Schultz, 1996). Insofar as the residuals in the wage regression are mainly based on ability

\footnotetext{
${ }^{15}$ See Hartog et al. (1998) for an application to returns to education in Portugal.

${ }^{16}$ Strictly speaking, this interpretation must rely on a counter-factual assumption - as in any model where the endogeneity of the regressors is not dealt with. The thought experiment would be: take a worker with 16 years of schooling at the 10 percent quantile of the wage distribution, give her one more year of schooling, assume that she stays at the 10 percent quantile and calculate the difference in earnings.

${ }^{17}$ See Ichino and Winter-Ebmer (1999) for an approach where returns to education for different groups are bounded by the use of different instrumental variables estimators.
} 
differences, higher returns for the higher quantiles suggest that more able individuals profit more from additional educational investment.

It is very interesting to note, that these phenomena - higher spread in returns to education over time and falling returns at the lower quartiles - is in contrast to the picture for the U.S. (Buchinsky, 1994), where returns increased steadily for all quantiles alike. ${ }^{19}$

To get a clearer picture as to what returns actually declined, we extend our quantile regression framework from years of schooling to educational levels. In Figures 9 and 10 we present estimates for the 25, 50 and 75 percentile for three educational levels (apprentice, secondary academic school (AHS) and university) as benchmark situations. For clarity of presentation we do not show results for the peripheral quantiles (.10 and .90) here, but also because of the higher volatility and the higher standard errors in the estimates of the extreme quantiles. $^{20}$ The results are again presented as percentage differences between the respective group and the baseline educational group, i.e. those with only compulsory schooling.

As before, returns to educational levels are in general higher for higher quantiles. Moreover, the variability of returns is much higher within the upper educational levels. This consideration of variability of returns makes sense, if the graduates of a specific school type are seen as a distinctive and homogeneous group. On the other hand, more years of education are required for university, so there is more room for variability in earnings. ${ }^{21}$ Note that variability of returns within educational levels did not increase as pronounced as the picture in Figures 7 and 8 (returns to years of schooling) would suggest. The reason is that compositional effects in a years-of-education-framework lead to spurious variability. ${ }^{22}$

Next we consider the development of returns over time. Returns to apprenticeship training remain practically constant over time for males and females. Likewise, returns to secondary academic schools are relatively constant over time, they drop somewhat in the last periods. In contrast to this, returns to university education drop considerably, especially for those in the lower quartile. Note, that returns in the 75 percentile for men stay constant until 1993, whereas those in the lower quartile drop steadily. Returns for female university graduates are more volatile, but drop considerably as compared to the period 1983-85. It seems that a part

\footnotetext{
${ }^{18}$ See also Gusenleitner et al. (1998) for a discussion of inequality in Austria using Gini coefficients using another data set.

${ }^{19}$ For Germany Fitzenberger et al. (1995) and Fitzenberger and Kurz (1998) perform similar analyses, but they concentrate more on age profiles and industry wages structures.

${ }^{20}$ Results for the other two educational groups as well as for all quantiles can be received upon request from the authors.

${ }^{21}$ We calculated also returns per year of education for each educational level separately. This calculation is somewhat arbitrary, because we have to assume how many years university graduates study. For a university graduate we have also to assign different returns to his years at high-school and his year in college.
} 
of the drops in returns is caused by lower returns for university graduates, who cannot find adequate positions. ${ }^{23}$ This can happen to those in the lower quantiles, but even more so for women in general.

\section{Conclusions}

In our assessment of returns to education in Austria we find falling returns over time, which is in contrast to most other countries, especially to the U.S. The general tendency of falling returns is consistent with a relatively high increase in the supply of more educated workers in the last two decades. Some special features require particular attention. Whereas workers in the higher quantiles of the earnings distribution managed more or less to maintain their earnings advantage, those in the lower part of the earnings distribution lost ground. This may be due to a phenomenon of downgrading of highly educated workers where more and more qualified workers are unable to find suitable positions according to their education. Definite answers to these questions are hard to give without making a causal interpretation of returns to education. This is beyond the scope of this paper, because a causal interpretation would require endogenizing of the schooling decision. Further work will have to expand this analysis by looking at ability measures as well as by searching for consistent instruments to tackle this important issue.

Buchinsky (1984) observed rising returns to education for all quantiles in the U.S. wage distribution and asks for a theory that could explain this specific feature. In Austria, the picture is more diverse. It seems not possible to explain the Austrian development within a unified theory. A potential theory should have the following ingredients: a rapid catching up in educational attainment, heterogeneity of returns, an increasing spread in the labour market qualifications of equally educated workers, which will lead to some problems of overeducation, and less weight for formal qualifications as such.

\footnotetext{
${ }^{22}$ To be more precise: variability in returns is lower for the less educated, as the number of less educated workers declines over time, variability of returns to education must increase.

${ }^{23}$ Lassnig et al. report in their survey on university graduates that for those who started their career in 1975 $(1985,1995), 6 \%(16 \%, 21 \%)$ started a job which was occupied by a high-school graduate before.
} 


\section{References}

Ashenfelter, Orley, Harmon, Colm and Hessel Oosterbeek (2000): A Review of Estimates of the Schooling/Earnings Relationship, with Tests for Publication Bias, Labour Economics, forthcoming.

Boss, Michael, Hofer, Helmut, Mitter, Peter and Josef Zweimüller (1997). Lebenseinkommen im Privaten und Öffentlichen Sektor. Institut for Advanced Studies, Vienna.

Buchinsky, Moshe (1994): Changes in the U.S. Wage Structure 1963-1987: An Application of Quantile Regression, Econometrica 62(2), 405-58.

Card, David (1999): The Causal Effect of Education on Earnings, in: Orley Ashenfelter and David Card (eds.), Handbook of Labor Economics, Volume 3, Amsterdam (NorthHolland), forthcoming.

Chevalier, Arnaud and Ian Walker (1999): Further Results on the Returns to Education in the $U K$, mimeo, University of Keele.

Christl, Josef (1984). The explanatory power of the human capital earnings function. Empirica 11(1), 47-57.

Deutsch, Edwin (1996): Beitrag der Ausländer zur Wohnbaufinanzierung und Sozialtransfers im Wohnungsbereich, in: Biffl, Gudrun, Deutsch, Edwin, Lutz, Hedwig und Markus Marterbauer (eds.), Ökonomische und Strukturelle Aspekte der Ausländerbeschäftigung in Österreich, Studie des Österreichischen Instituts für Wirtschaftsforschung.

Dolton, Patrick J. and Anna Vignoles (1997): Graduate Overeducation: A European Perspective, Higher Education in Europe 22/4, 475-484.

Fersterer, Josef and Rudolf Winter-Ebmer (1999a): Human Capital and Earnings in Austria, in: Asplund, Rita and Pedro Telhado Pereira (eds.), Returns to Human Capital in Europe - A Review of the Literature, ETLA, Helsinki.

Fersterer, Josef and Rudolf Winter-Ebmer (1999b): Returns to Education: Evidence for Austria, Arbeitspapier \# 9913, University of Linz, Austria.

Fitzenberger, Bernd, Hujer, Reinhard, MaCurdy, Thomas E. and Reinhold Schnabel (1995): The Dynamic Structure of Wages in Germany 1976-1984. A Cohort Analysis, DP 22, University of Konstanz.

Fitzenberger, Bernd and Claudia Kurz (1998): New Insights on Earnings Trends across Skill Groups and Industries in West Germany, Empirical Economics, forthcoming. 
Goldin, Claudia (1998): America's Graduation from High-School: The Evolution and Spread of Secondary Schooling in the Twentieth Century, Journal of Economic History 58, 345374.

Gusenleitner, Markus, Winter-Ebmer, Rudolf and Josef Zweimüller (1998): Income Distribution: Austria 1972-1991, Allgemeines Statistisches Archiv, 82/3, 275-290.

Hartog, Joop, Pereira, Pedro T.and José A.C. Vieira (1998): Changing Returns to Education in Portugal During the 1980s and Early 1990s: OLS and Quantile Regression Estimators, mimeo, Tinbergen Institute, Amsterdam.

Hofer, Helmut and Karl Pichelmann (1997): A note on earning inequality in Austria, mimeo, IHS, Vienna.

Hungerford, Thomas and Gary Solon (1987): Sheepskin Effects in the Returns to Education, The Review of Economics and Statistics 69, 175-177.

Ichino, Andrea and Rudolf Winter-Ebmer (1998): The Long-run Educational Cost of World War II: An Example of Local Average Treatment Estimation, WP 9802, University of Linz.

Ichino, Andrea and Rudolf Winter-Ebmer (1999): Lower and Upper Bounds of Returns to Schooling: An Exercise in IV Estimation with Different Instruments, European Economic Review 43/4-6, 889-902.

Katz, Lawrence F. and Kevin M. Murphy (1992): Changes in Relative Wages, 1963 - 1987: Supply and Demand Factors. The Quarterly Journal of Economics, 35-78.

Koenker, Roger and Gilbert Basset Jr. (1982): Robust Tests for Heteroscedasticity Based on Regression Quantiles. Econometrica 50(1), 43-61.

Lassnigg, Lorenz, London, Susanne, Schramm, Brigitte and Peter Steiner (1998): Zur Beschäftigung von Hochschulabsolventen, mimeo, IHS, Vienna.

Lauer, Charlotte and Viktor Steiner (1999): Returns to Human Capital in Germany: An Empirical Analysis, mimeo, ZEW, Mannheim.

Mwabu, Germano and Paul T. Schultz (1996): Education Returns Across Quantiles of the Wage Function: Alternative Explanations for Returns to Education by Race in South Africa, American Economic Review Papers and Proceedings 86, 335-339.

Psacharopoulos, George (1994): Returns to Investment in Education: A Global Update, World Development 22, 1325-1343.

Sicherman, Nachum (1991): Overeducation in the Labor Market, Journal of Labor Economics 9, 101-122. 
Tunali, Insan (1986): A General Structure for Models of Double-Selection and an Application to a Joint Migration/Earnings Process with Re-Migration, in: Ehrenberg, Ron (ed.), Research in Labor Economics, Vol 8/B, Greenwich (JAI), 235-284.

Zweimüller, Josef and Rudolf Winter-Ebmer (1994): Gender Wage Differentials in Private and Public Sector Jobs, Journal of Population Economics 7, 271-285.

Zweimüller, Josef (1992): Survey non-response and biases in wage regressions, Economics Letters 39, 105-109. 
Table 1: Estimates of Basic Mincer Equation 1981 - 1997: Males

\begin{tabular}{|c|c|c|c|c|c|c|c|c|c|}
\hline & 1981 & 1983 & 1985 & 1987 & 1989 & 1991 & 1993 & 1995 & 1997 \\
\hline Years of Schooling & $\begin{array}{c}0.100 \\
(0.002)\end{array}$ & $\begin{array}{c}0.095 \\
(0.002)\end{array}$ & $\begin{array}{c}0.095 \\
(0.002)\end{array}$ & $\begin{array}{c}0.091 \\
(0.002)\end{array}$ & $\begin{array}{c}0.095 \\
(0.002)\end{array}$ & $\begin{array}{c}0.087 \\
(0.002)\end{array}$ & $\begin{array}{c}0.093 \\
(0.002)\end{array}$ & $\begin{array}{c}0.080 \\
(0.002)\end{array}$ & $\begin{array}{c}0.074 \\
(0.002)\end{array}$ \\
\hline Experience (Potential) & $\begin{array}{c}0.033 \\
(0.001)\end{array}$ & $\begin{array}{c}0.036 \\
(0.001)\end{array}$ & $\begin{array}{c}0.036 \\
(0.001)\end{array}$ & $\begin{array}{c}0.030 \\
(0.001)\end{array}$ & $\begin{array}{c}0.032 \\
(0.001)\end{array}$ & $\begin{array}{c}0.030 \\
(0.001)\end{array}$ & $\begin{array}{c}0.027 \\
(0.001)\end{array}$ & $\begin{array}{c}0.029 \\
(0.001)\end{array}$ & $\begin{array}{c}0.024 \\
(0.001)\end{array}$ \\
\hline Experience squared ${ }^{\text {a) }}$ & $\begin{array}{l}-0.049 \\
(0.002)\end{array}$ & $\begin{array}{l}-0.053 \\
(0.002)\end{array}$ & $\begin{array}{c}-0.051 \\
(0.002)\end{array}$ & $\begin{array}{l}-0.040 \\
(0.002)\end{array}$ & $\begin{array}{l}-0.044 \\
(0.002)\end{array}$ & $\begin{array}{l}-0.040 \\
(0.003)\end{array}$ & $\begin{array}{c}-0.031 \\
(0.003)\end{array}$ & $\begin{array}{l}-0.039 \\
(0.003)\end{array}$ & $\begin{array}{l}-0.028 \\
(0.003)\end{array}$ \\
\hline Constant & $\begin{array}{c}2.628 \\
(0.022)\end{array}$ & $\begin{array}{c}2.725 \\
(0.024)\end{array}$ & $\begin{array}{c}2.773 \\
(0.024)\end{array}$ & $\begin{array}{c}2.944 \\
(0.023)\end{array}$ & $\begin{array}{c}2.991 \\
(0.025)\end{array}$ & $\begin{array}{c}3.206 \\
(0.026)\end{array}$ & $\begin{array}{c}3.249 \\
(0.026)\end{array}$ & $\begin{array}{c}3.439 \\
(0.023)\end{array}$ & $\begin{array}{c}3.550 \\
(0.026)\end{array}$ \\
\hline $\mathrm{R}^{2}$ adj. & 0.288 & 0.306 & 0.319 & 0.297 & 0.292 & 0.264 & 0.275 & 0.284 & 0.275 \\
\hline Sample Size & 9889 & 8416 & 8120 & 8519 & 7878 & 7333 & 7175 & 7219 & 5386 \\
\hline
\end{tabular}

Note: Standard errors in parenthesis

a) parameter multiplied by the factor 100 
Table 2: Estimates of Basic Mincer Equation 1981 - 1997: Females

\begin{tabular}{|c|c|c|c|c|c|c|c|c|c|}
\hline & 1981 & 1983 & 1985 & 1987 & 1989 & 1991 & 1993 & 1995 & 1997 \\
\hline Years of Schooling & $\begin{array}{c}0.114 \\
(0.003)\end{array}$ & $\begin{array}{c}0.114 \\
(0.003)\end{array}$ & $\begin{array}{c}0.110 \\
(0.003)\end{array}$ & $\begin{array}{c}0.094 \\
(0.003)\end{array}$ & $\begin{array}{c}0.103 \\
(0.003)\end{array}$ & $\begin{array}{c}0.100 \\
(0.004)\end{array}$ & $\begin{array}{c}0.090 \\
(0.003)\end{array}$ & $\begin{array}{c}0.079 \\
(0.002)\end{array}$ & $\begin{array}{c}0.080 \\
(0.003)\end{array}$ \\
\hline Experience (Potential) & $\begin{array}{c}0.031 \\
(0.001)\end{array}$ & $\begin{array}{c}0.031 \\
(0.001)\end{array}$ & $\begin{array}{c}0.032 \\
(0.001)\end{array}$ & $\begin{array}{c}0.027 \\
(0.001)\end{array}$ & $\begin{array}{c}0.025 \\
(0.001)\end{array}$ & $\begin{array}{c}0.020 \\
(0.002)\end{array}$ & $\begin{array}{c}0.022 \\
(0.002)\end{array}$ & $\begin{array}{c}0.017 \\
(0.001)\end{array}$ & $\begin{array}{c}0.014 \\
(0.002)\end{array}$ \\
\hline Experience squared ${ }^{\text {a) }}$ & $\begin{array}{l}-0.050 \\
(0.003)\end{array}$ & $\begin{array}{l}-0.050 \\
(0.003)\end{array}$ & $\begin{array}{l}-0.046 \\
(0.003)\end{array}$ & $\begin{array}{l}-0.043 \\
(0.003)\end{array}$ & $\begin{array}{l}-0.033 \\
(0.003)\end{array}$ & $\begin{array}{l}-0.016 \\
(0.005)\end{array}$ & $\begin{array}{l}-0.029 \\
(0.004)\end{array}$ & $\begin{array}{l}-0.017 \\
(0.003)\end{array}$ & $\begin{array}{l}-0.010 \\
(0.004)\end{array}$ \\
\hline Part-time $(0,1)^{b)}$ & $\begin{array}{c}0.078 \\
(0.012)\end{array}$ & $\begin{array}{c}0.105 \\
(0.013)\end{array}$ & $\begin{array}{c}0.111 \\
(0.013)\end{array}$ & $\begin{array}{c}0.080 \\
(0.011)\end{array}$ & $\begin{array}{c}0.052 \\
(0.012)\end{array}$ & $\begin{array}{c}0.080 \\
(0.016)\end{array}$ & $\begin{array}{c}0.051 \\
(0.011)\end{array}$ & $\begin{array}{c}0.032 \\
(0.009)\end{array}$ & $\begin{array}{c}0.026 \\
(0.010)\end{array}$ \\
\hline Constant & $\begin{array}{c}2.275 \\
(0.036)\end{array}$ & $\begin{array}{c}2.382 \\
(0.036)\end{array}$ & $\begin{array}{c}2.437 \\
(0.037)\end{array}$ & $\begin{array}{c}2.766 \\
(0.032)\end{array}$ & $\begin{array}{c}2.763 \\
(0.037)\end{array}$ & $\begin{array}{c}2.843 \\
(0.046)\end{array}$ & $\begin{array}{c}3.110 \\
(0.035)\end{array}$ & $\begin{array}{c}3.357 \\
(0.030)\end{array}$ & $\begin{array}{c}3.410 \\
(0.034)\end{array}$ \\
\hline $\mathrm{R}^{2}$ adj. & 0.249 & 0.288 & 0.278 & 0.245 & 0.235 & 0.163 & 0.218 & 0.220 & 0.231 \\
\hline Sample Size & 5222 & 4572 & 4718 & 4968 & 4572 & 4905 & 4473 & 4704 & 3494 \\
\hline
\end{tabular}

Note: Standard errors in parenthesis

a) parameter multiplied by the factor 100

b) parameter transformed by $\exp (\beta)-1$ 
Table 3: Income non-response 1981 - 1997

\begin{tabular}{lccccccccc}
\hline & $\mathbf{1 9 8 1}$ & $\mathbf{1 9 8 3}$ & $\mathbf{1 9 8 5}$ & $\mathbf{1 9 8 7}$ & $\mathbf{1 9 8 9}$ & $\mathbf{1 9 9 1}$ & $\mathbf{1 9 9 3}$ & $\mathbf{1 9 9 5}$ & $\mathbf{1 9 9 7}$ \\
\hline $\begin{array}{l}\text { Men } \\
\text { \% income not reported }\end{array}$ & 22.27 & 33.00 & 35.49 & 29.82 & 30.53 & 34.86 & 32.04 & 38.96 & 54.29 \\
$\begin{array}{l}\% \text { income not reported } \\
\text { among univ. graduates }\end{array}$ & 38.11 & 48.39 & 49.21 & 42.03 & 44.55 & 47.69 & 42.79 & 50.25 & 56.33 \\
$\begin{array}{l}\text { Women } \\
\text { \% income not reported }\end{array}$ & 21.64 & 32.78 & 35.31 & 29.69 & 30.19 & 34.97 & 36.10 & 37.12 \\
$\begin{array}{l}\text { \% income not reported } \\
\text { among univ. graduates }\end{array}$ & 38.98 & 50.49 & 36.67 & 39.13 & 45.76 & 43.48 & 46.86 & 45.97 & 50.70 \\
\hline
\end{tabular}


Table 4: Austria: Highest completed level of education (in \%)

\begin{tabular}{|c|c|c|c|c|c|c|}
\hline & \multicolumn{2}{|c|}{1981} & \multicolumn{2}{|c|}{1991} & \multicolumn{2}{|c|}{$\%$ change 81/91 } \\
\hline & males & females & males & females & males & females \\
\hline Compulsory schooling & 40.4 & 61.7 & 31.5 & 50.6 & -22.1 & -18.0 \\
\hline Apprenticeship & 39.4 & 16.6 & 44.0 & 21.4 & 11.7 & 29.3 \\
\hline \multicolumn{7}{|l|}{ secondary (upper) } \\
\hline Vocational schools & 7.0 & 13.3 & 7.5 & 14.9 & 8.1 & 12.2 \\
\hline Secondary academic & 4.0 & 3.4 & 5.2 & 5.1 & 30.0 & 49.8 \\
\hline Vocational colleges & 4.5 & 2.7 & 5.6 & 3.7 & 24.9 & 36.4 \\
\hline \multicolumn{7}{|l|}{ tertiary } \\
\hline University & 4.8 & 2.3 & 6.2 & 4.2 & 30.1 & 85.2 \\
\hline
\end{tabular}

Table 5: USA: Highest completed level of education (in \%)

\begin{tabular}{lcccccc}
\hline & \multicolumn{2}{c}{1981} & \multicolumn{2}{c}{1991} & \multicolumn{2}{c}{ change 81/91 } \\
& males & females & males & females & males & females \\
\hline Elementary & 16.7 & 16.7 & 11.0 & 10.3 & -34.2 & -38.6 \\
High School & 46.6 & 55.2 & 46.5 & 52.4 & -0.2 & -5.1 \\
College & 36.7 & 28.1 & 42.5 & 37.4 & 15.8 & 33.0 \\
\hline
\end{tabular}

Source: U.S. Bureau of the Census 1981/1991, Population aged 15 years and older. 
Figure 1: The impact of sample selection: returns to education 1981-1997

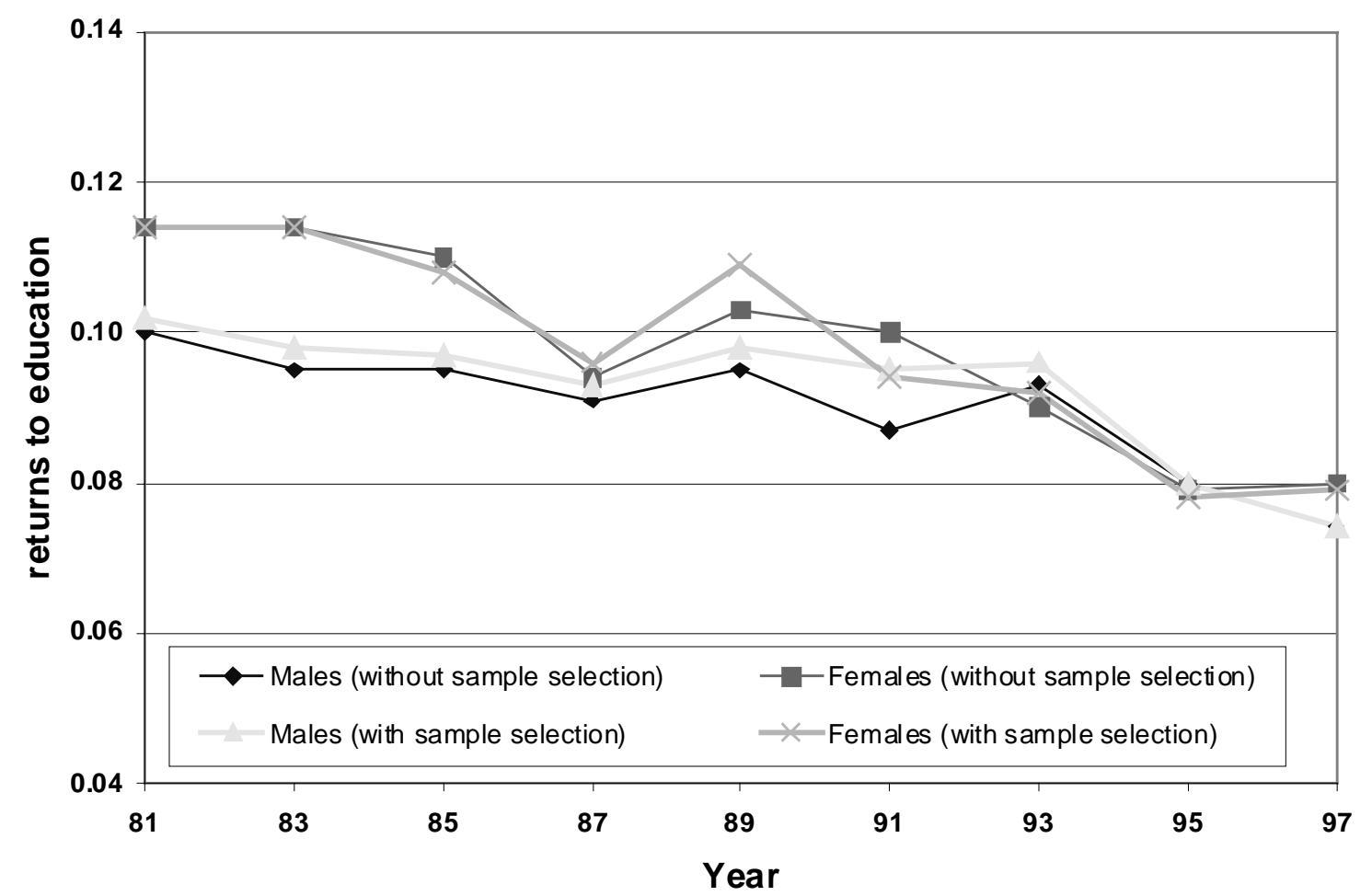


Figure 2: Changes in relative supply vs. changes in relative wages between 1981 and 1997

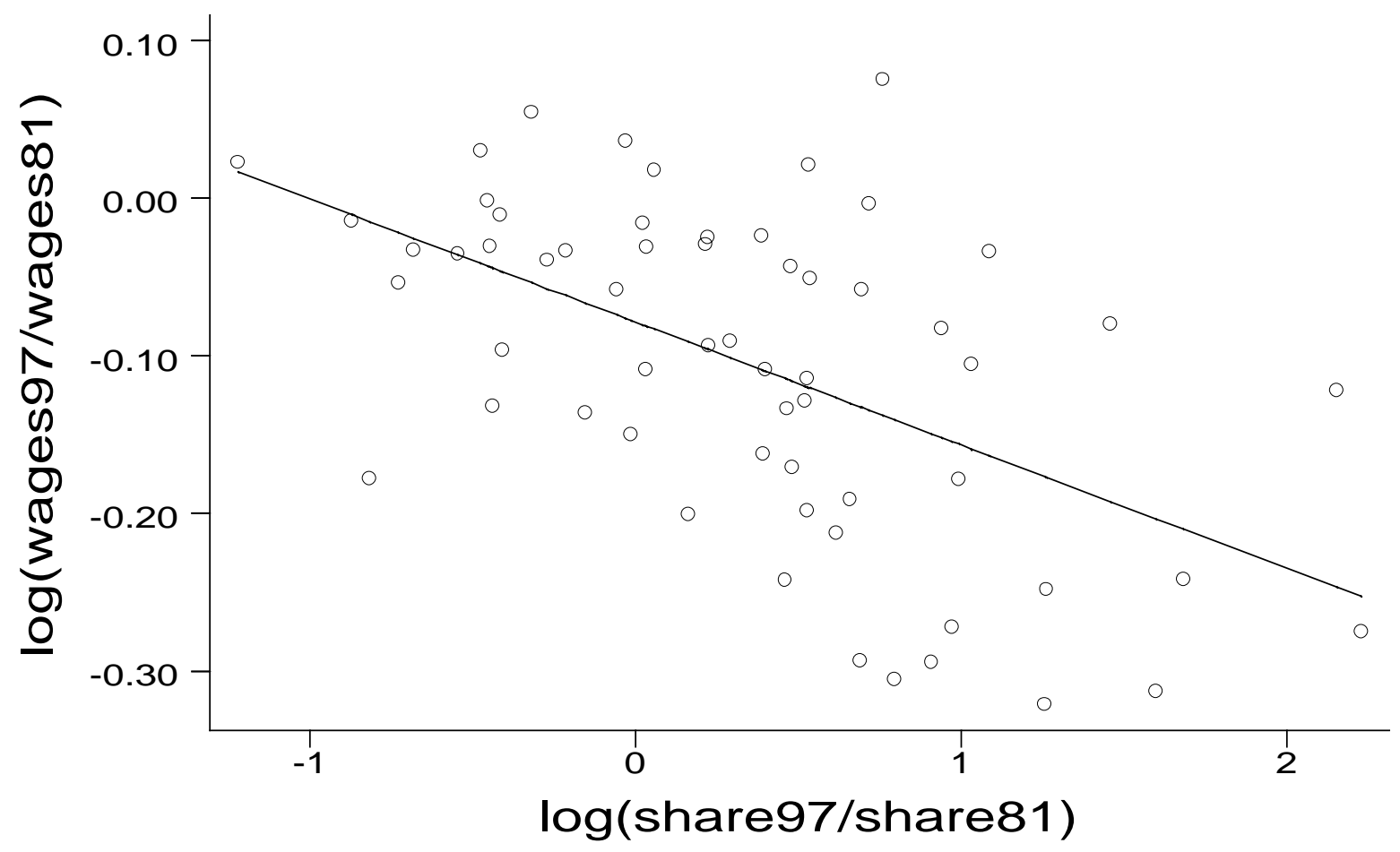


Figure 3: Returns to educational levels 1981 - 1997: Males

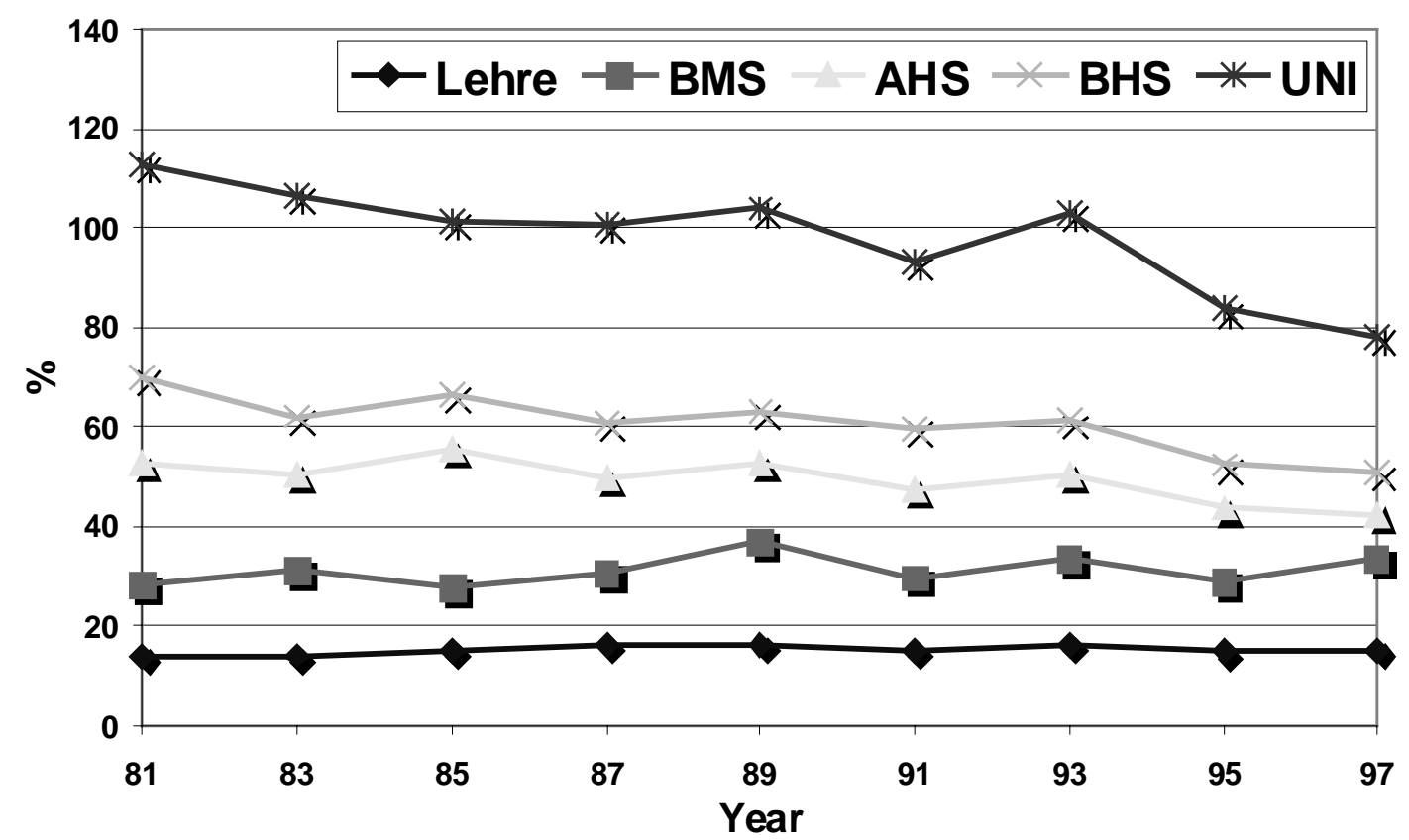

Figure 4: Returns to educational levels 1981 - 1997: Females

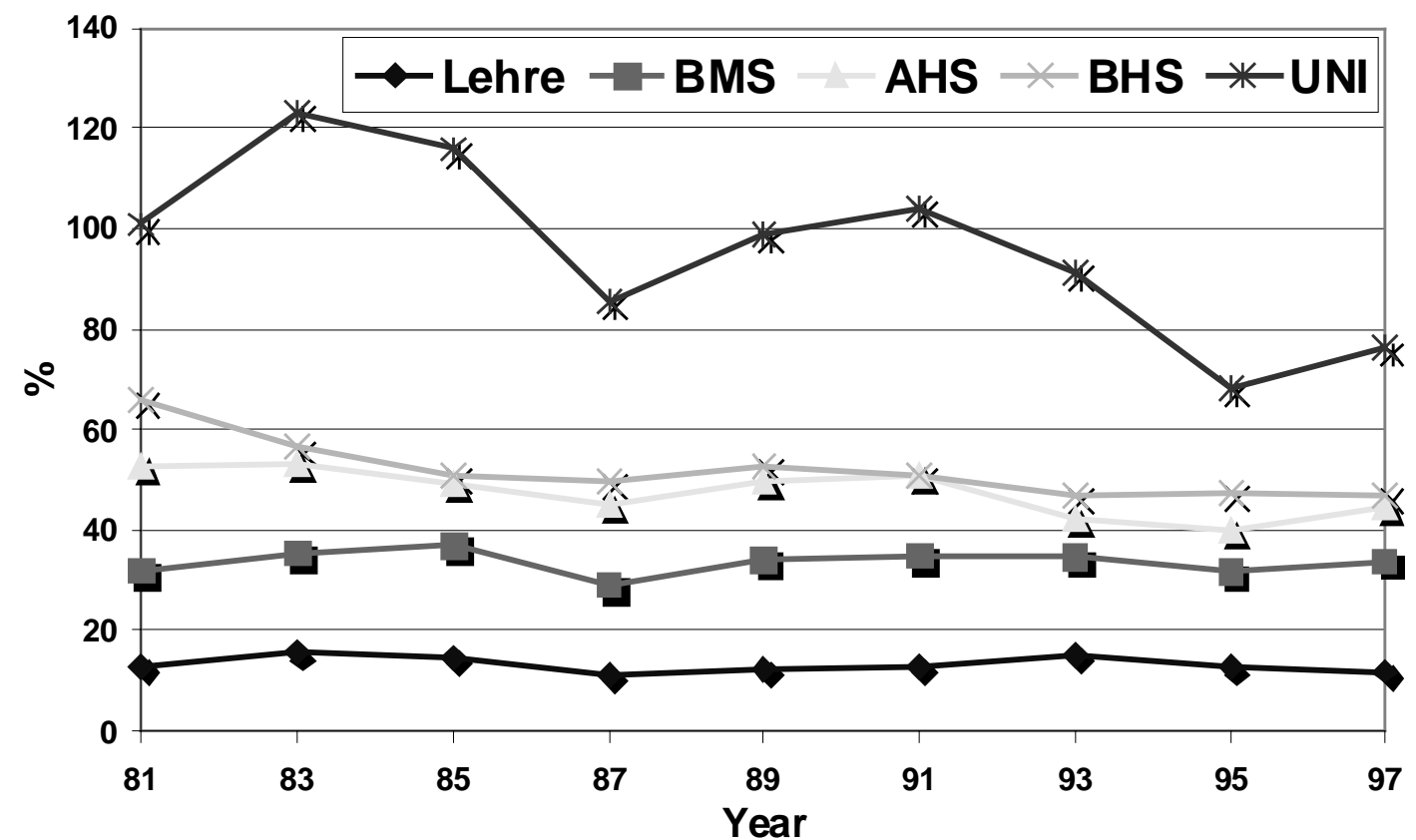

Note: Lehre: Apprenticeship training; BMS: vocational schools (2-3 year courses); AHS: secondary academic schools; BHS: vocational colleges (5 year courses); UNI: University degree 
Figure 5: Kernel density estimates ${ }^{24}$ for years of schooling and quantile regression lines $(\theta=0.1,0.5$ and 0.9$)$ for males $(1981)$

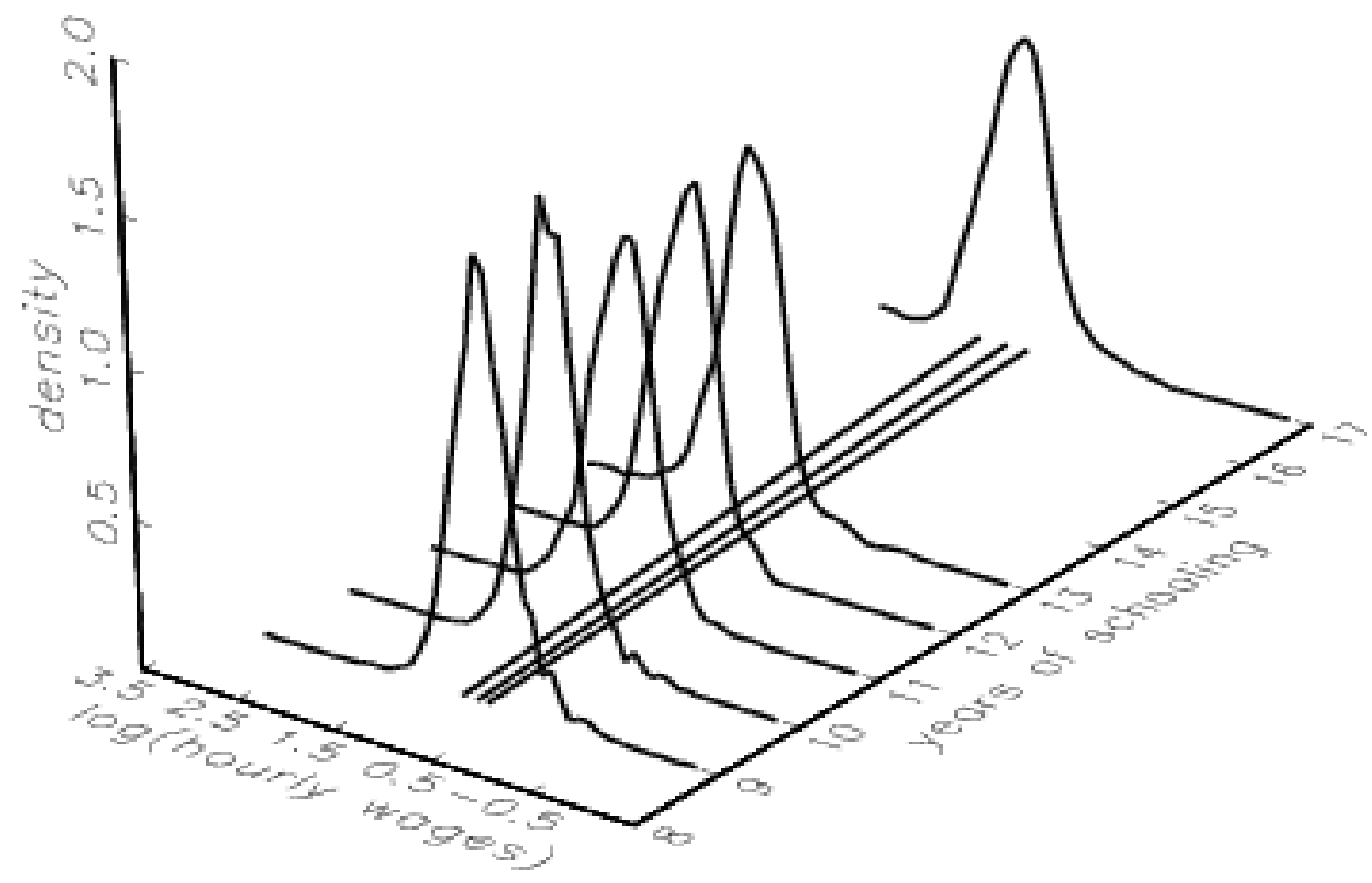

Figure 6: Kernel density estimates for years of education and quantile regression lines $(\theta=0.1,0.5$ and 0.9$)$ for males $(1993)$

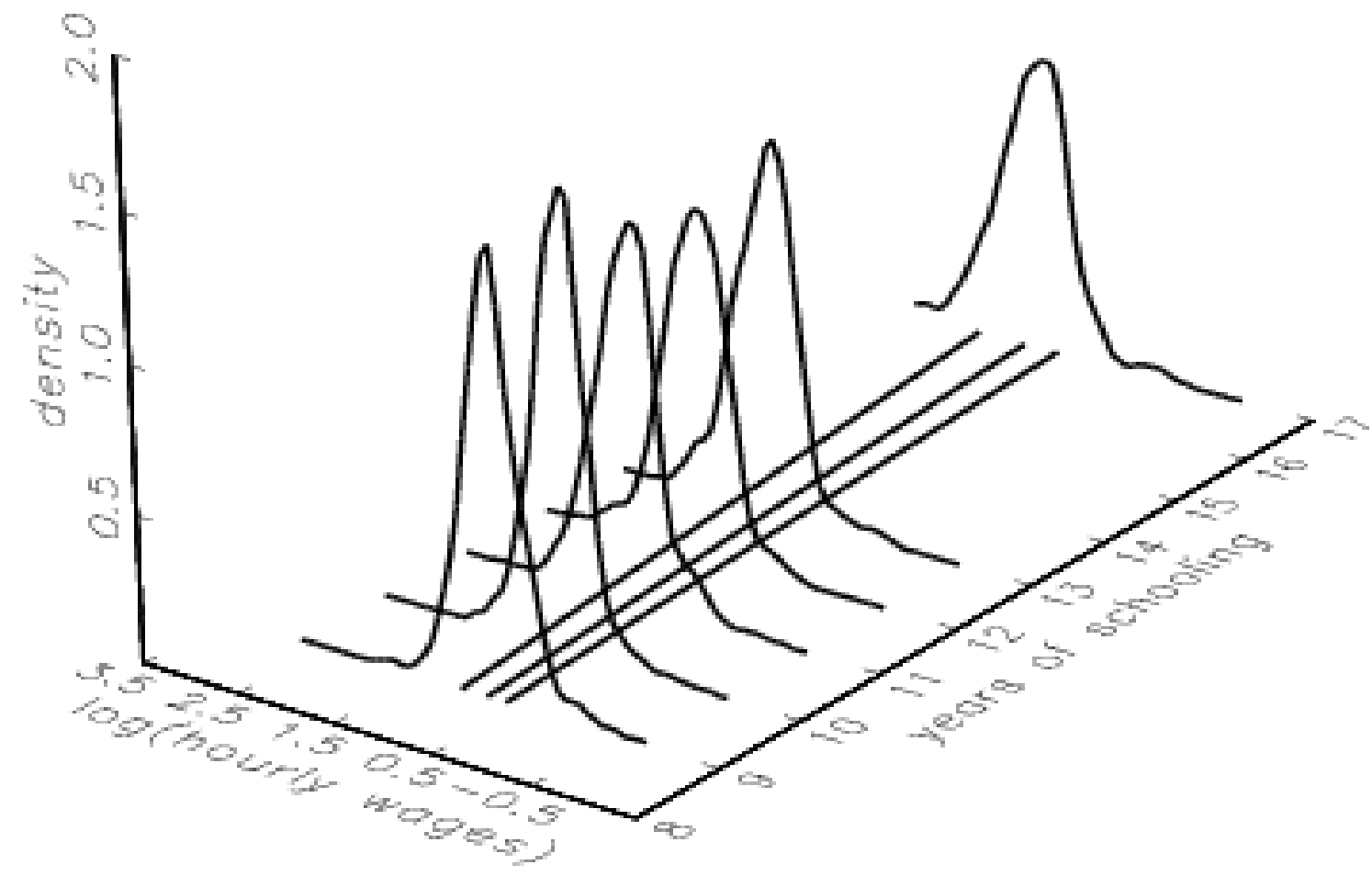

\footnotetext{
${ }^{24}$ Kernel density estimates capture the variation of $\log$ wages after partialing out the influence of experience (potential) and experience squared on wages.
} 
Figure 7: Quantile Regressions 1981 - 1997: Males

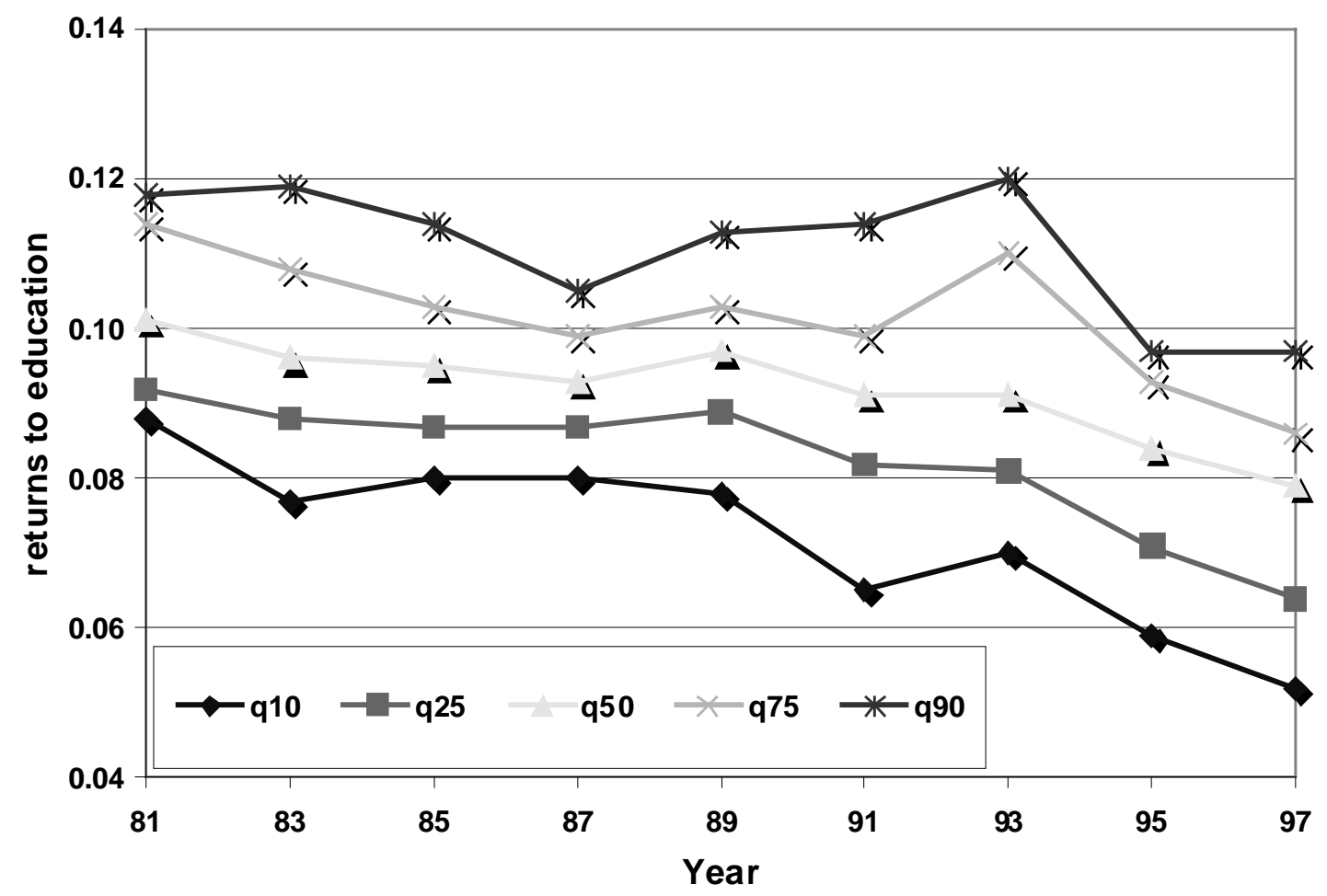

Figure 8: Quantile Regressions 1981 -1997: Females

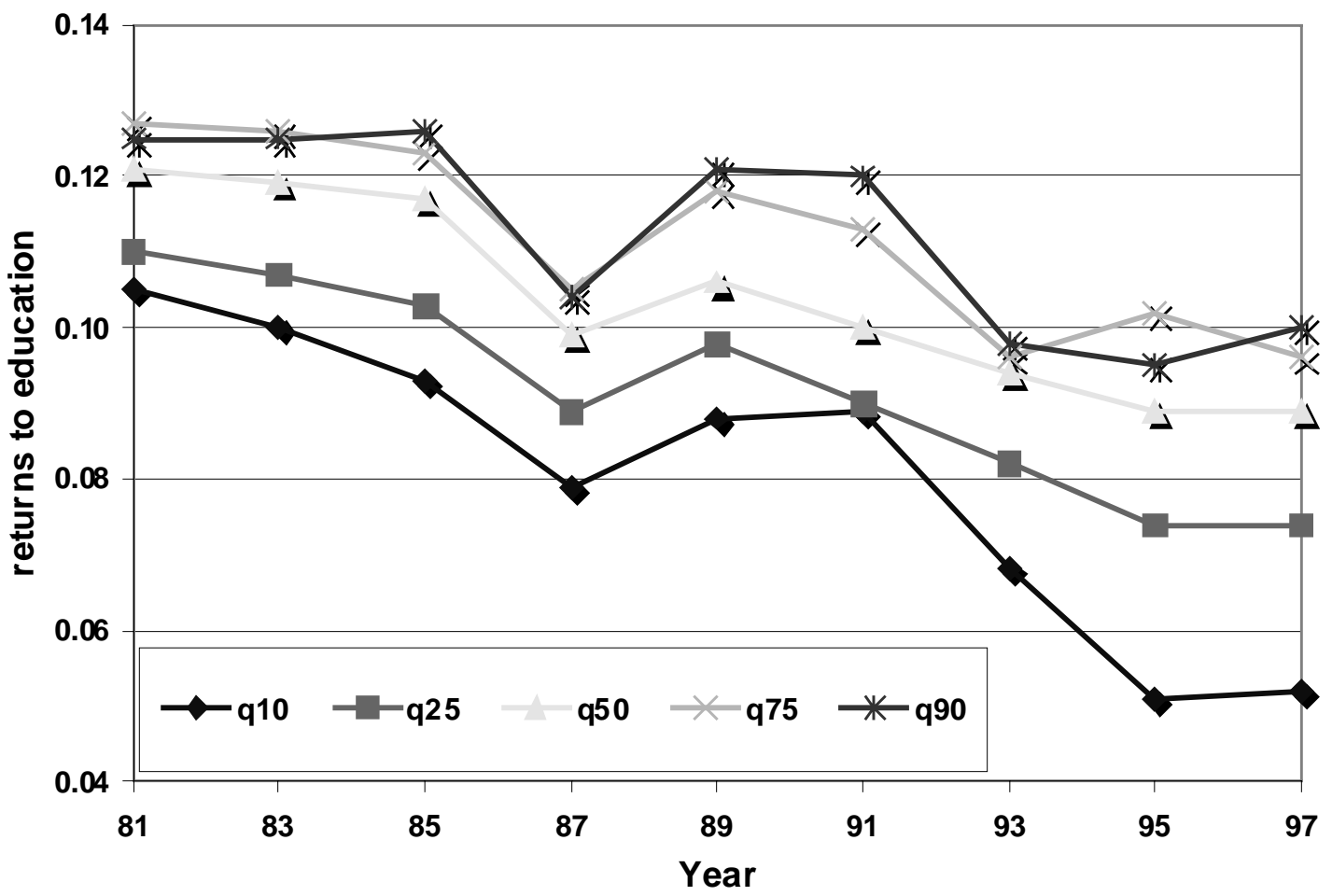


Figure 9: Quantile Regressions for selective educational levels 1981 -1997:

Males, returns relative to compulsory education.

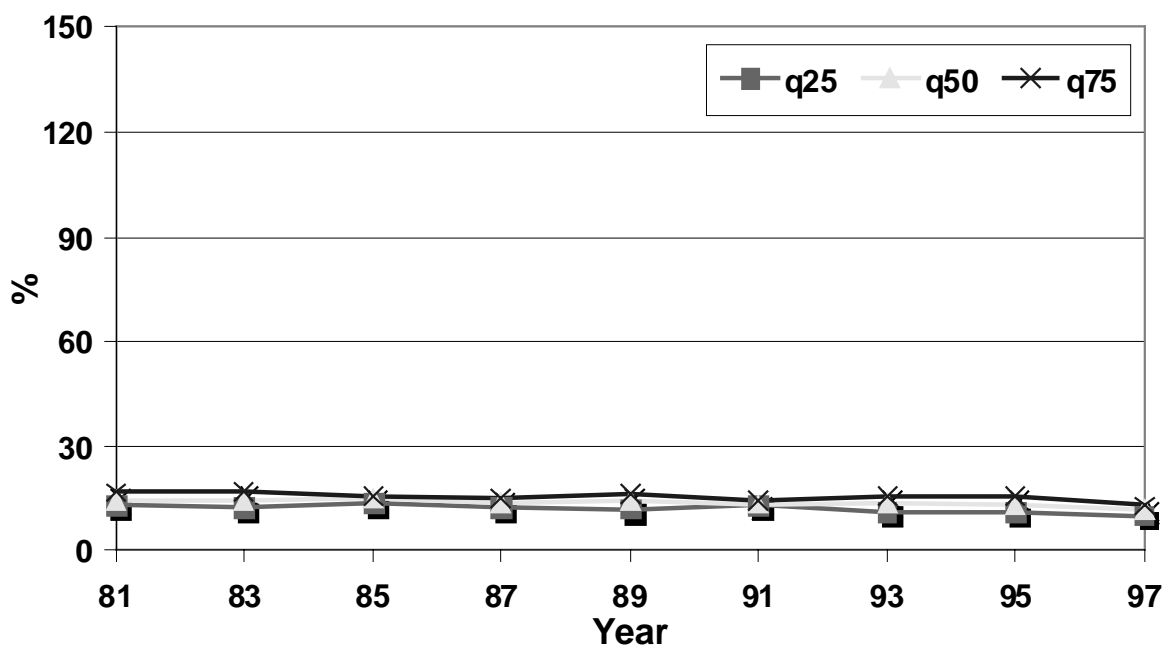

Apprentice training

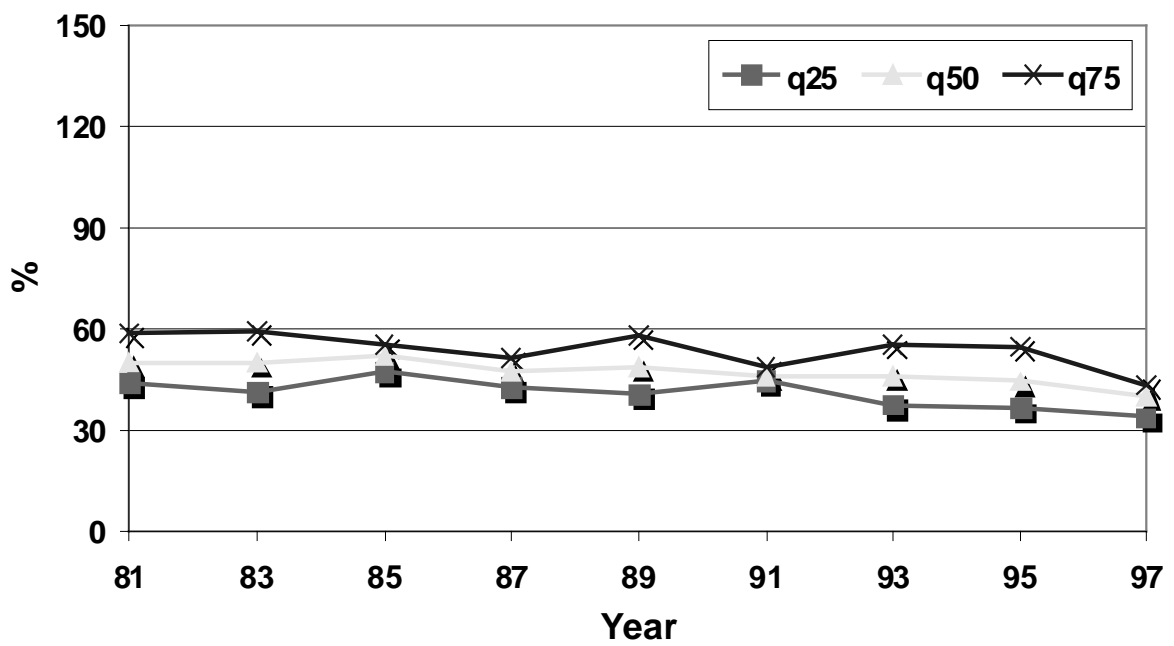

Secondary academic school

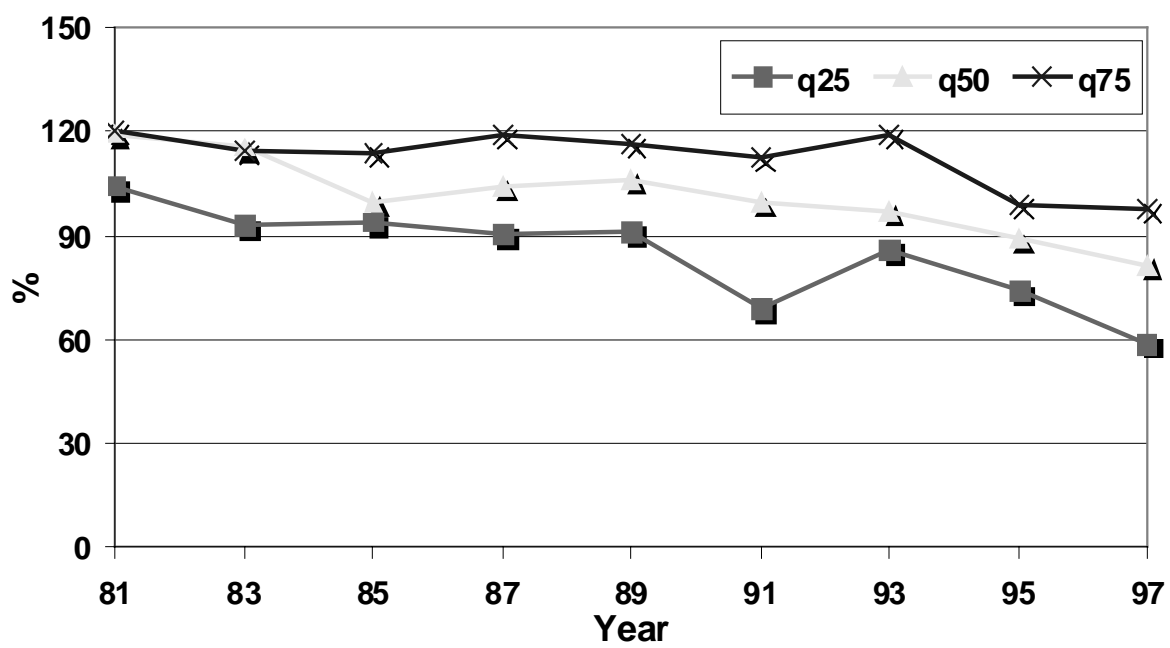

University 
Figure 9: Quantile Regressions for selected educational levels 1981 -1997:

Females, returns relative to compulsory education.

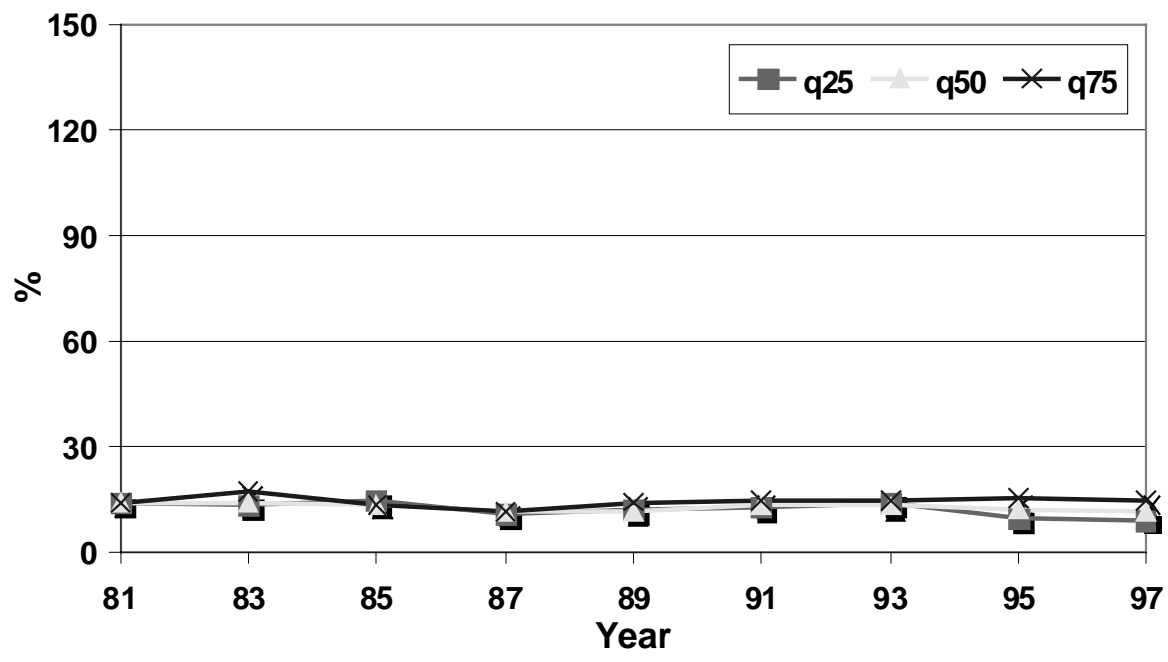

Apprentice training

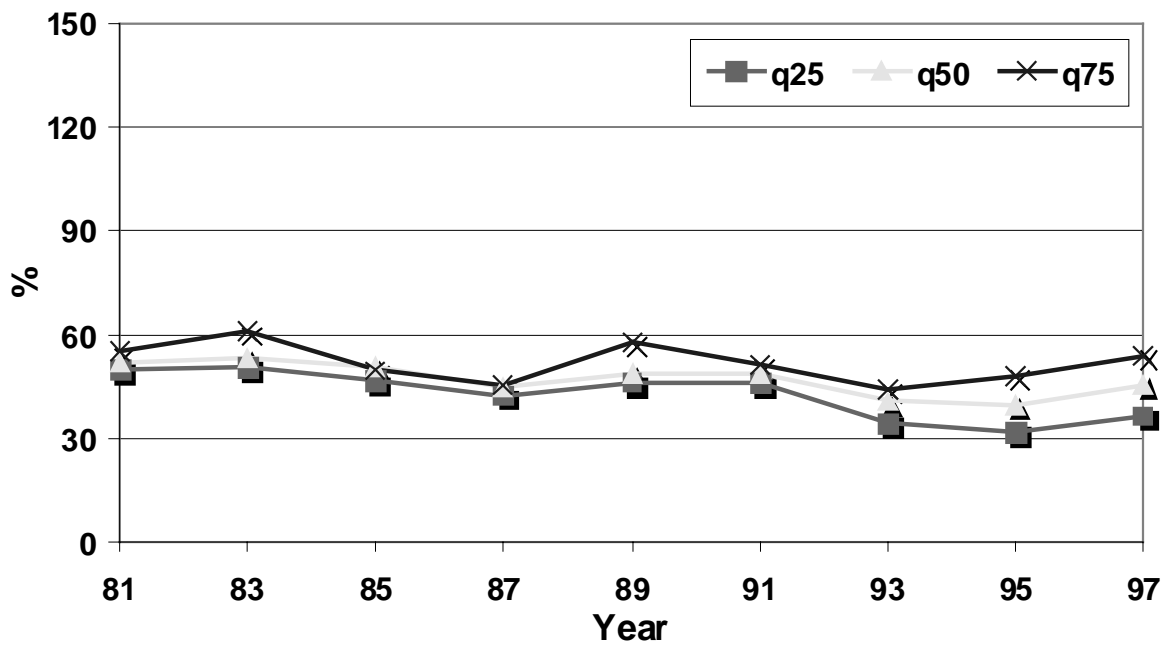

Academic secondary school

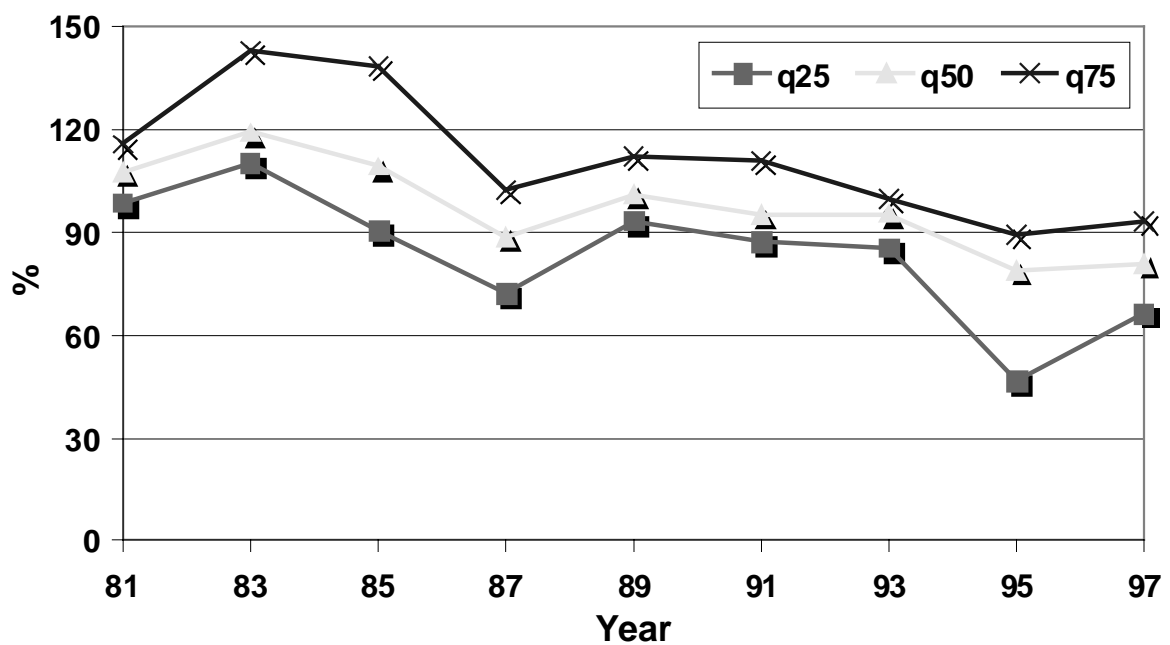

University 


\section{Appendix}

Table A1: The impact of sample selection (1991)

Men

Women

\section{Sample selection model}

\section{Income reported (No/Yes)}

$\begin{array}{lcr}\text { years of schooling } & -0.053(0.007) & -0.051(0.010) \\ \text { age } & 0.006(0.008) & -0.034(0.010) \\ \text { age squared }^{\text {a) }} & -0.014(0.010) & 0.031(0.014) \\ \text { self report } & 0.341(0.024) & 0.427(0.034) \\ \text { constant } & 0.754(0.151) & 1.420(0.191)\end{array}$

\section{Participation equation}

years of schooling

$\begin{array}{ll}-- & 0.098(0.009) \\ -- & 0.061(0.011) \\ -- & -0.144(0.013) \\ -- & -1.065(0.043) \\ -- & -1.062(0.042) \\ -- & -0.754(0.036) \\ -- & -0.733(0.039) \\ -- & -0.609(0.035) \\ -- & 0.389(0.023)\end{array}$

age

age squared $^{\text {a) }}$

partner (base: no partner)

partner employed

partner not employed

$.754(0.151)$

$1.420(0.191)$

\# children 0-3 yrs

\# children 4-6 yrs

\# children 7-9 yrs

\# children 10-15 yrs

\section{Wage equation}

$\begin{array}{lrr}\text { years of schooling } & 0.095(0.002) & 0.102(0.003) \\ \text { experience } & 0.029(0.001) & 0.021(0.001) \\ \text { experience squared }^{\text {a) }} & -0.037(0.003) & -0.021(0.003) \\ {\text { part-time }(0,1)^{\text {b) }}}_{\text {constant }} & -- & 0.036(0.001) \\ \lambda \text { report } & 3.247(0.027) & 3.024(0.037) \\ \lambda \text { participation } & -0.208(0.013) & -0.169(0.053) \\ \end{array}$

\section{Sample Size}

Participation equation

Income equation (Income reported)

Wage equation

Note: standard errors in parenthesis
a) parameter multiplied by the factor 100
b) parameter transformed by $\exp (\beta)-1$. 